сущность и место в системе экономической бюезопасности. [Электронный ресурс]. Режим доступа: http://studbooks.net/1009/finansy/mehanizm_ sistemy_obespecheniya_finansovoy_bezopas nosti_gosudarstva]

8. Усик I. Тенденції економічного розвитку територій України // Схід. - №2 (148) березень-квітень 2017. - С. 22 - 26.

9. Офіційний сайт Державної служби статистики України. [Електронний ресурс]. - Режим доступу: www.ukrstat.gov.ua. Назва з екрана.

10. Минфин - Финансовый портал. Электронный ресурс. - Режим доступа: http:// minfin.com.ua/.

11. Науменко А. М. Напрями підвищення дохідності місцевих бюджетів / А. М. Науменко // Держава та регіони. 2009. - № 5. - C. 127 - 133.

12. Кірдіна О. Г. Обмеження та орієнтири техніко-технологічного розвитку України в умовах глобалізації / О. Г. Кірдіна // Маркетинг і менеджмент інновацій. - 2011. - №4. - С. 179 - 184.

13. Жаворонков Р.А. Финансовые проблемы регионов Украины: институционный аспект. [Электронный pecypc]. - Режим доступа: http://institutiones.com/general/2468-

finansovye-problemy-regionov-ukrainy.html

14. Жаворонков В.А. Финансовые проблемы регионов Украины: институциональный аспект // Научнотехнические ведомости СПбГПУ. Экономические науки. - №6(209). - 2014. C. $164-170$.

15. Дикань О.В., Новак Т.А. Теоретичні та методологічні підходи до стратегії інвестиційної привабливості України // Вісник економіки і промисловості. - 2017. - № 59. - С. 195 199.

\title{
МЕХАНІЗМИ ПРИВЕДЕННЯ ДЕРЖАВНОГО АНТИМОНОПОЛЬНОГО РЕГУЛЮВАННЯ УКРАЇНИ ДО СТАНДАРТІВ СС
}

\author{
Украӥнська Л.О., о.е.н., професор, \\ Соболева I.В., аспірант (ХНЕУ ім. С. Кузнеця)
}

Виконано дослідження умов та причин наближення національного законодавства України до антимонопольних стандартів Свропейського Союзу. Здійснено аналіз механізмів наближення національного законодавства України до антимонопольних стандартів Європейського Союзу. Запропоновано механізми приведення стандартів антимонопольного регулювання України до норм СС. Розкрито дії антимонопольних органів України з гармонізації конкурентної ситуації в країні в аспекті євроінтеграції.

Ключові слова: Свропейський союз, конкуренція, антимонопольний стандарт, Україна, монополізм. 


\title{
МЕХАНИЗМЫ ПРИВЕДЕНИЯ ГОСУДАРСТВЕННОГО АНТИМОНОПОЛЬНОГО РЕГУЛИРОВАНИЯ УКРАИНЫ К СТАНДАРТАМ ЕС
}

\author{
Украинская Л.О., д.э.н., профессор, \\ Соболева И.В., аспирант (ХНЭУ им. С. Кузнеща)
}

\begin{abstract}
Выполнень исследования условий и причин приближения национального законодательства Украины к антимонопольным стандартам Европейского Союза. Осуществлен анализ механизмов приближения национального законодательства Украинь $к$ антимонопольным стандартам Европейского Союза. Предложень механизмы приведения стандартов антимонопольного регулирования Украины $к$ нормам ЕС. Раскрыты действия антимонопольных органов Украины по гармонизации конкурентной ситуации в стране в аспекте евро интеграции.
\end{abstract}

Ключевые слова: Европейский союз, конкуренция, антимонопольный стандарт, Украина, монополизм.

\section{MECHANISMS OF ENHANCING THE STATE ANTI-MONOPOLY REGULATION OF UKRAINE TO THE EU STANDARDS}

\author{
Ukrainska L.O., Doctor of Economic Sciences, full professor, \\ Soboleva I.V., Postgraduate Student (S. KUZNETS KhNUE)
}

An Association Agreement between Ukraine and the EU, aimed at European integration, requires the development of appropriate standards, in particular regarding antitrust policy. A high proportion of monopolization of national and regional markets is actualizing this issue, since they indicate an inadequate state anti-monopoly policy. The purpose of this article is to study the mechanisms of bringing the standards of antimonopoly regulation of Ukraine to the EU norms. The course on integration with the EU puts Ukraine in the task of bringing Ukrainian anti-monopoly regulation to the EU standards. Analyzing antitrust regulation in Ukraine, the main developments should be based on: the system of bodies and institutions to be specially created and functioning for regulatory approximation of EU antitrust standards to the requirements of national legislation, by conducting regulatory monitoring in order to identify gaps in national legislation and to provide recommendations for their elimination; the activities of bodies and institutes in the area of the fulfillment of their tasks and functions in relation to the approximation of national legislation to the EU standards. Approximation of Ukraine's legislation to the EU standards is an important task of our state in the context of the ongoing European integration processes, appropriate legal, organizational, economic, institutional mechanisms must be created for effective realization of this task. The introduction of these mechanisms should take into account the national specifics of the development of a competitive environment in the country.

Key words: European Union, competition, antitrust standard, Ukraine, monopoly.

Постановка проблеми. На сьогодні перед українською державою постає завдання 3 приведення механізмів державного управління до стандартів Європейського Союзу (ЄС). Угода про асоціацію між Україною та $\mathrm{CC}$, що націлена на євроінтеграцію потребує розробки відповідних стандартів, зокрема стосовно антимонопольної політики. Висока частка монополізації 
національного та регіональних ринків актуалізують дану проблематику, оскільки вказують на недостатню ефективність державної антимонопольної політики. У зв'язку з цим, склалася нагальна потреба у стратегічній модернізації антимонопольних стандартів 3 метою забезпечення захисту інтересів суб'єктів ринку від обмежувальної практики, недобросовісної конкуренції, а також антиконкурентних дій. Для ефективного досягнення визначених пріоритетів, в умовах триваючих євроінтеграційних процесів нашої країни, методи і механізми державного впливу повинні бути адекватні новим явищам в економіці, гармоніювати 3 принциповими змінами в теорії та практиці антимонопольного правового поля, запровадженого в Європейському Союзі, що сприятиме формуванню інституційних умов функціонування конкурентних ринків. Вищенаведене й обумовило необхідність проведення дослідження 3 даного напряму.

Аналіз останніх досліджень $\boldsymbol{i}$ публікацій. Окремі аспекти приведення стандартів антимонопольного регулювання України до норм СС досліджено у наукових працях таких науковців, як Н.Я. Барсук, С.С. Валітов, В.М. Грудницький [4], Б.В. Деревянко, А.В. Замрига, Калініна О.М. [8], Н.В. Мирко, А.В. Немчіков [2], В.М. Павліченко, В.М. Шумилов [1], та інші науковці.

Виділення невирішених частин загальної проблеми. Разом з тим, ті зміни, що тривають в економічній сфері, які на внутрішньодержавному, так i на наднаціональному рівні, потребуються актуалізації наявних досліджень та більш детального розгляду механізмів приведення стандартів антимонопольного регулювання України до норм СС.

Метою cmammi $\epsilon$ дослідження механізмів приведення стандартів антимонопольного регулювання України до норм $\mathrm{CC.}$
Виклад основного матеріалу. Курс на інтеграцію з СС ставить перед Україною завдання 3 приведення українського антимонопольного регулювання до стандартів СС. 3 моменту створення ЄЕС, проблема підтримки конкуренції на належному рівні була однією 3 основних економічних і інституційних завдань для європейської спільноти. Досягнення бажаних ефектів спільного ринку потребувало від європейських держав проголошення домінанти відкритої конкурентної ринкової економіки на рівні публічних правовідносин. Таким чином, за основу була покладена концепція, що виключає дискримінацію економічних свобод на державному рівні. Підписання Україною Угоди про асоціацію між Україною та Європейським Союзом, потребує відповідно вжиття заходів щодо забезпечення в країні конкурентного середовища. Подібне завдання не можливе без наближення національного правового поля до антимонопольних стандартів $€ С$ за допомогою спеціальних механізмів [1, с. 5].

В українському господарському законодавстві загальні традиції європейського континентального права залишаються домінуючими, що обумовлює i близькість антимонопольного регулювання України до стандартів СС за формальними критеріями, відображеними в Регламенті і Директивах Ради ЄС. Разом 3 тим, можливість перенесення антимонопольних стандартів 3 одного порядку в інший без фундаментальних трансформацій, а шляхом звичайного запозичення не $\epsilon$ можливим. Розробка системи механізмів приведення стандартів антимонопольного регулювання до норм ЄC може здійснюватися в різних межах. Аналізуючи антимонопольне регулювання в Україні, основні розробки повинні спиратися на:

1) системі органів та інститутів, що мають бути спеціально створені та функціонувати в цілях нормативного наближення антимонопольних стандартів 
ЄС до вимог національного законодавства, шляхом провадження нормативного моніторингу з метою виявлення прогалин у національному законодавстві та надання рекомендацій відносно їх усунення;

2) діяльності органів та інститутів в сфері виконання своїх завдань і функцій щодо наближення національного законодавства до стандартів СС;

3) процесі здійснення належних суб'єктам господарювання, гарантованих антимонопольними стандартами $\mathrm{CC}$ прав і повноважень, їх юридичної охорони та захисту;

4) системі нормативів, що визначають статус антимонопольних стандартів ЄС відносно системи національного законодавства, і суб'єктів, уповноважених та зобов'язаних використовувати і застосовувати дані стандарти, а також контролювати дотримання і виконання цих повноважень i обов'язків;

5) системі фінансового забезпечення втілення антимонопольних стандартів СС.

В економічній теорії поняття «механізм» визначається як система, устрій, що визначає порядок будь-якого виду діяльності. Механізм - послідовність станів, процесів, що визначають собою яку-небудь дію, явище. Даний термін часто використовується в поєднанні 3 такими дефініціями, як "економічний", "правовий", "організаційний" та ін. Отже, при використанні поняття "механізм" передбачається створення такої системи (економічної, господарської, організаційної), яка забезпечує постійне керуючий вплив, спрямований на досягнення визначених результатів діяльності [2, с. 7$]$.

3 метою приведення стандартів антимонопольного регулювання України до норм ЄС мають бути розроблені ефективні механізми реалізації даного завдання нашої держави, серед яких слід виокремити: правовий, організаційний, інституційний, економічний механізми.
Важливе місце серед зазначених механізмів належить саме правовому механізмові. Правовий механізм приведення стандартів антимонопольного регулювання України до норм ЄС полягає:

1) в імплементації положень директив ЄС в національне законодавство України;

2) гармонізації діючих національних актів в сфері антимонопольного регулювання у відповідність 3 нормативно - правовими актами України;

3) вилучення окремих національних актів в сфері антимонопольного регулювання, які не узгоджуються 3 стандартами $\epsilon \mathrm{C}, 3$ системи чинного національного законодавства;

4) заповненні прогалин в національному законодавстві в сфері антимонопольного регулювання, шляхом прийняття нових правових актів на виконання чинних директив СС.

Сьогодні в межах правового механізму перед суб'єктами на яких покладено завдання моніторингу національного законодавства стоїть визначний обсяг аналітичної роботи задля виявлення невідповідності національного законодавства стандартам ЄС. На відміну від України, в праві ЄС на нормативному рівні закріплено позицію, згідно 3 якою недобросовісна конкуренція відноситься до сфери інтелектуальної власності, у зв'язку 3 чим, підпадає під правове регулювання не тільки антимонопольного законодавства, а й законодавства про інтелектуальну власність. Таким чином, для європейського антимонопольного законодавства характерна проблема його взаємодії 3 законодавством в області промислової власності. Йдеться про конфлікт антимонопольного права 3 патентної монополією (винятковим правом на винахід та інші об'єкти промислової власності). У праві більшості держав це протиріччя долається шляхом узаконення так званих легальних монополій, в число яких входить і патентна. На практиці зазначена проблема виникає при 
включенні обмежувальних умов у патентні ліцензійні договори i в договори про відступлення (продаж) різноманітних об'єктів промислової власності, ноу-хау. Найчастіше обмежувальна торгова практика регламентується окремими підзаконними нормативними актами, в яких визначається характер (законний або протиправний) тих чи інших обмежувальних умов.

Наступним механізмом $\epsilon$ організаційний механізм приведення стандартів антимонопольного регулювання України до норм СС, що полягає у створенні та налагодженні упорядкованого процесу запровадження зазначених європейських стандартів та нормативних документів, регламентуючих реалізацію зазначеного процесу. Діяльність щодо впровадженню певного антимонопольного стандарту повинна розпочинатись 3 формування робочої групи, в яку повинні увійти правники, посадові особи структурних підрозділів сфер діяльності, які перебувають в зоні антиконкурентного ризику, працівники антимонопольного органу та представники суб'єктів господарювання, що перебувають в зоні потенційної антиконкурентної небезпеки, та представники громадських організацій. Має бути надане відповідне забезпечення для організації роботи такої групи.

Важливе місце серед досліджуваних механізмів, займає економічний механізм, що полягає у створенні відповідних важелів впливу на суб'єктів господарювання, сукупність яких створить підгрунтя для зацікавленості суб'єктів господарювання у дотриманні оновлених антимонопольних стандартів. Методи впливу держави на соціально-економічні процеси застосовуються в ціновому, грошово-кредитному, фінансовобюджетному i адміністративному регулюванні.

Економічний механізм в свою чергу розглядається як ринковий, що поєднує саморегулювання господарюючих суб'єктів з регулюючими функціями держави. Так, згідно 3 антимонопольними приписами $\mathrm{EC}$, в країнах - членах ЄС, на відміну від України, займати домінуюче становище не заборонено, забороняється зловживання домінуючим становищем. ЄС залишає за собою право контролю за діяльністю підприємця, що займає домінуюче становище, з метою підтримати існування конкуренції на ринку.

Правове врегулювання даного питання знайшло своє закріплення, насамперед, в одному з основоположних актів СС - Амстердамському договорі. Протиправність зловживання домінуючим становищем ставиться в залежність від ступеня шкоди, до якої може призвести таке діяння в межах вільної торгівлі між державами - членами ЄС. Разом 3 тим, монополістична конкуренція характеризується вищим ступенем загальності, ніж чиста конкуренція в тому контексті, що включає в себе і монополію і конкуренцію i поєднує їx у можливих варіаціях, повністю охоплюючи макроекономічну систему.

Подібне повне охоплення створює велику перевагу, оскільки відношення до оцінки монополій змінюється від бачення в ній іï негативного впливу на конкуренцію до зваженого розуміння іiі місця і ролі в розвитку національної економіки. Крім того, цей підхід є ключем до розуміння того явища, що глобалізація значною мірою змінює уявлення про географічні межі товарних ринків - важливої категоріальної складової антимонопольного регулювання [2, с. 8].

У якості ще одного економічного важелю впливу можна навести цінове регулювання. В даному випадку необгрунтовані дії держави, що виражаються в зниженні або підвищенні цін, можуть спричинити негативний вплив на конкуренцію, так як певне підприємство може отримати перевагу перед конкурентами. У той же час визнання допомоги незаконною не означає, що дана 
допомога чинить негативний вплив i шкодить конкуренції в тій мірі, в якій вона суперечить положенням статті 107 Договору про функціонування ЄС [3].

$\mathrm{He}$ можна оминути увагою інституційний механізм, сутність якого полягає у створенні розвиненої інституціональної структури .

Інституціональна структура може набувати власного розвитку за двома напрямками:

- копіювання антимонопольних інституцій та їх складових в успішних країн, що входять до складу $\mathrm{EC}$;

- побудова власної інституційної структури, 3 врахуванням національних особливостей розвитку сфери конкуренції господарської діяльності, з орієнтацією на існуючі антимонопольні стандарти ЄС.

Такі вимоги засновані на особливостях активної конкурентної політики, пред'являє високі вимоги до стандартів захищеності прав власності та контрактних прав i відповідно безпосередньо пов'язана 3 такими ключовими характеристиками порядку відкритого доступу, як верховенство права, свобода входу.

Ще одна важлива проблема, на яку слід звернути увагу в межах інституціонального механізму, - це надмірний для ринкової економіки контроль i протекціонізм, які часто виходять від держави 3 огляду на дублювання функцій окремих інституцій. Монополістичні або протекціоністські дії держав - членів ЄC розглядаються в більшості випадків у якості несумісних зі спільним ринком. Саме тому в країнах $\mathrm{CC}$ нівелюється економічний протекціонізм і були засновані правила конкуренції, що регулюють не тільки приватну економічну діяльність, але i втручання держави в ринкову діяльність. Під забороною знаходиться будь-яка форма допомоги, що надається державою-членом у вигляді дотації або за рахунок державних ресурсів, яка порушує або загрожує порушити конкуренцію. Заборона діє лише в тій мірі, в якій названа державна преференція i подальше за нею обмеження конкуренції впливають на торгівлю між державами членами СС [4, с. 61].

Підприємства, на які покладено управління службами загального економічного інтересу або становлять собою за своїм характером фіскальну монополію, повинні підкорятися правилам конкуренції, відтворених у Договорі про функціонування ЄС. Встановлено i обмеження антимонопольного законодавства щодо названих державних підприємств: ці норми застосовуються «в тій мірі, в якій застосування цих положень не підриває, юридично або фактично, виконання ними спеціальних завдань, які на них покладені» [4, с. 61]. Слід відзначити що, незважаючи на відносну досконалість антимонопольного регулювання $\mathrm{CC}$, проте, перед ним до сих пір стоїть загроза дискримінації, яка здійснюється суб'єктами приватної форми власності через практики, що обмежують конкуренцію (тарифні угоди, демпінг, примушування до укладення договорів певного характеру і т.п.).

Рішенням проблеми стало проведення $\mathrm{CC}$ загальної політики в області конкуренції, під якою можна розуміти узгоджені на правовому рівні дії та плани, спрямовані на запобігання порушень конкуренції в рамках спільного ринку. Тобто, загальна політика в даній області спрямована на запобігання суперництва між учасниками ринкового господарювання за кращі умови виробництва, купівлі-продажу товарів i отримання на цій основі максимально можливого прибутку.

$$
\text { В Свропейському Союзі }
$$
антимонопольні стандарти $\epsilon$ не тільки гарантією функціонування простору без внутрішніх кордонів, а й обов'язковою умовою існування вільної ринкової економіки, захищеної від втручання з боку держави i монополістичних дій підприємств, що порушують вільну конкуренцію. Метою антимонопольного 
регулювання в $\mathrm{CC}, \epsilon$ створення спільного ринку з діючої конкуренцією. Крім того, норми про конкуренцію, закладені в установчих договорах, мають також мету досконалої інтеграції країн - членів $\mathrm{CC}$, та потенційних нових учасників $€ C$ до європейського економічного простору. Україна зі свого боку має впроваджувати наявні стандарти та активно розробляти механізми з приведення антимонопольного регулювання до стандартів $€$ С.

Висновки. Вищенаведене дозволяє зробити наступні висновки:

1) наближення законодавства

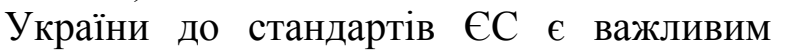
завданням нашої держави в умовах триваючих євроінтеграційних процесів;

2) для ефективної реалізації даного завдання мають бути створені відповідні правовий, організаційний, економічний, інституційний механізми;

3) запровадження даних механізмів має враховувати національну специфіку розвитку конкурентного середовища в країні.

Перспективою

подальших досліджень є подальше більш грунтовне дослідження механізмів та принципів антимонопольного регулювання країн СС 3 метою впровадження результатів в діяльність органів АМКУ та його регіональних відділень.

\section{ПЕРЕЛІК ВИКОРИСТАНИХ ДЖЕРЕЛ}

1. Шумилов В. Договор о ЕАЭС : основа Евразийской интеграции / В.Шумилов // Евразийский юридический журнал. - 2012. - №5 (48) - С. 5-7.

2. Немчиков А. Конкурентная политика Европейского Союза на современном этапе / А. Немчиков // Мировая экономика. - 2011. - №3. - С. 310.

3. Договор о функционировании Европейского Союза // Европейский Союз: Основополагающие акты в редакции Лиссабонского договора с комментариями / Отв. ред. С. Кашкин. - М.: НИЦ ИНФРАM, 2013. - 698 c.

4. Грудницький В. Гармонізація національного законодавства про зловживання монопольним (домінуючим) становищем із правом Свропейського Союзу / В. Грудницький // Підприємництво, господарство и право. 2017. - № 4. - С. 59-63.

5. Угода про асоціацію між Україною, 3 однієї сторони, та Європейським Союзом, Європейським співтовариством 3 атомної енергії і їхніми державами-членами, 3 іншої сторони : Міжнародний документ СЕС від 27 червня 2014 р. // Офіційний вісник України. 2014. - № 75. - Т. 1. - Ст. 2125

6. Договор о Европейском Союзе // Европейский Союз: Основополагающие акты в редакции Лиссабонского договора с комментариями / Отв. ред. С.Ю. Кашкин. М.: НИЦ ИНФРА-М, 2013. - 698 с.

7. Commission Decision on State aid SA.21918 (C 17/07) (ex NN 17/07) implemented by France // Official Journal of European Union. - 2012. - C 398. - P. 10-30. Par. 12, 168.

8. Калініна О. М. Правове регулювання діяльності компаній в Свропейському союзі [Текст] : автореф. дис. ... канд. юрид. наук: 12.00.11 / O.M. Калініна. - К., 2014. - 22 с.

DOI 10.18664/338.47:338.45.v0i64.149960 